\title{
ROLE OF BIO AND ORGANIC FERTILIZATION ON SUSTAINING NITROGEN REQUIREMENTS FOR RICE PRODUCTION
}

Azza R. Ahmed; M.A. Bayoumi; H.M. Khalil and M.S. Awaad.

Soils, Water and Environ. Res. Inst., Agric. Res. Center, Giza, Egypt

\begin{abstract}
A field experiment was performed on a clay soil at Bahtim Agriculture Research Station during season 2009 to evaluate the effective role of bio (blue green algae, $\mathrm{BGA}$ ), organic manure (farmyard, $\mathrm{FYM}$ ) in combination with two $\mathrm{N}$-mineral sources, urea $(46 \% \mathrm{~N})$ and urea-formaldehyde $(40 \% \mathrm{~N})$ at different rates $(0,30,45$ and $75 \mathrm{~kg}$ $\mathrm{N} /$ fed) on rice growth parameters, yield and $\mathrm{N}$-use efficiency as well as some soil properties.
\end{abstract}

The obtained results revealed that the greatest values of the studied growth parameters, i.e., plant height, number of tillers $/ \mathrm{m}^{2}$ as well as 1000 grain weight, straw and grain yields (biological yield) were achieved at the highest $\mathrm{N}$-rate of ureaformaldehyde combined with BGA. Nitrogen use efficiency was affected by the applied different treatments; however, the total $\mathrm{N}$-uptake was higher with ureaformaldehyde at the rate of $75 \mathrm{~N} \mathrm{~kg} / \mathrm{fed}$, as compared to urea, combined with either $\mathrm{BGA}$ or FYM. This was true, since urea-formaldehyde is characterized by $\mathrm{N}$-slow release during the growth stages of rice crop. Also, total $\mathrm{N}$-uptake was more pronounced with the applied recommended dose of urea-formaldehyde (90 kg N/fed) as compared to urea.

Moreover, application of the combined treatment of urea-formaldehyde + FYM resulted in the greatest soil organic matter content, total nitrogen and available nitrogen as compared to the other applied treatments, contrary the reverse trend was true for soil $\mathrm{pH}$. Concerning the water stable aggregates, soil aggregate size distribution was more affected by the applied different treatments. However, soil aggregation exhibited an improvement towards the application of urea-formaldehyde or urea combined with FYM.

So, the application of natural bio and organic manures, i.e., blue green algae or local organic farmyard manure with urea formaldehyde are considered the best option not only for maximizing rice grain yield, its quality and reducing the harmful effects of using nitrogenous chemical fertilizers, but also for sustaining soil fertility status. Moreover, the application of bio-organic manures leads to rationalize use of $\mathrm{N}$-mineral fertilizer for the growing crop, which is surplus point for sustainable agriculture system, as well as represents a solving for the problems of chemical residues in the export market commodities.

Keywords: Urea, urea-formaldehyde, blue green algae, organic manures, rice

\section{INTRODUCTION}

Rice is one of the most important summer annual crops grown in Egypt; however, it is mainly cultivated in flooded soils. Thus, the soil-fertilizer regime is completely different from other upland crops, particularly in regard to the behavior of applied fertilizer nitrogen (Allen, 1984). It is well known that nitrogen fertilization plays a significant role in improving rice yield, where a high rate of nitrogen application increases leaf area development, improves leaf area duration after flowering and increases the overall crop assimilation and thus contributing to increased seed yield (Hussein and Radwan, 2001). 
Azza R. Ahmed et al.

Kreem (1993) found that increasing nitrogen application rates increased number of tillers/hill, number of filled grains/spike, 1000 grain weight and grain yield. Namely, the nitrate contained in the fertilizer or converted from ammonia prior to submerging are entirely lost under flooded soil conditions through denitrification. Therefore, ammonium- $\mathrm{N}$ or amide- $\mathrm{N}$ is stable form of nitrogen in this soil condition and fertilizers such as ammonium sulfate, urea etc... have been used preferentially in the fertilization of wetland rice. However, even these nitrogen fertilizers are applied as basal treatment, the nitrogen recoveries by rice are still not high (20-40\%) due to strongly leaching condition in paddy soil (Shoji and Mae, 1984). The release pattern of controlled availability fertilizer (CAF) is reported to be synchronized with the growth rate of the crop. Neelam and Chopra (2000) stated that the highest values of plant height, number of panciles $/ \mathrm{m}^{2}$, seed weight/panicle, panicle length, grain and straw yields were obtained when the nitrogen fertilizers rates increased up to $80 \mathrm{~kg} \mathrm{~N} \mathrm{ha}^{-1}$.

The high cost of chemical nitrogenous fertilizers and the low purchasing power of most of the farmers restrict its use in proper amounts, hampering crop production. Besides, a substantial amount of the urea- $\mathrm{N}$ is lost through different mechanisms including ammonia volatilization, denitrification and leaching losses, causing environmental pollution problems (De Datta and Buresh, 1989; Choudhury and Kennedy, 2005). Hence, the efficiency of added urea- $\mathrm{N}$ is very low, often only 30-40\% and, in some cases, even lowers (Choudhury and Khanif, 2004).

A controlled release of fertilizer nitrogen may increase $\mathrm{N}$ use efficiency by rice plants and at the same time reduce adverse environmental impacts associated with $\mathrm{N}$ loss. It may also be able to supply nitrogen as nitrate to rice even in the flooded soil, because the root of rice may contact to (CAF) fertilizer particles without burning and thus can adsorb the nitrate- $\mathrm{N}$ directly from them.

The utilization of blue green algae (BGA) technology can decrease the use of $\mathrm{N}$-mineral, prevent the depletion of soil organic matter and reduce environmental pollution to a considerable extent. Yield increases in rice due to inoculation of BGA are reported to be in the 22.0-44.0\% (Bhuiya et al., 1984; and Begum et al., 1990). Blue green algae make a valuable contribution to the fertility of many soils, and so to the yield of plants. The role of blue green algae is supplying $\mathrm{N}$ to rice field is well documented. In addition, they also bring about, directly or indirectly, a number of changes in the physical, chemical and biological properties of the soil and soil-water interface in rice fields (Mandal et al., 1999). Blue green algae liberate extra cellular organic compounds and photosynthetic $\mathrm{O}_{2}$ during their growth and on decomposing of different organic acid in soil (Rogers and Ladha, 1992). All changes brought about by BGA in soil may ultimately influenced plantavailable nutrients.

Organic matter makes its greatest contribution to soil productivity. It provides nutrients to the soil, improves its water holding capacity, and helps the soil to maintain good tilth and thereby better aeration for germinating seeds and plant root development (Zia, 1993). Soil organic matter encourages granulation, increases cation exchange capacity and is 
responsible for adsorbing power of the soils up to $90 \%$. Cations such as $\mathrm{Ca}$, $\mathrm{Mg}$ and $\mathrm{K}$ are produced during decomposition (Brady, 2005).

The objective of this study aimed to identifying the effective role of bio (blue green algae) and organic manure (farmyard) in combination with two Nmineral sources (urea and urea-formaldehyde) at different rates on rice growth parameters, $\mathrm{N}$-use efficiency, straw and grain yields as well as some soil properties.

\section{MATERIALS AND METHODS}

To achieve the aforementioned target, a field experiment was conducted on rice (Oryza sativa L., var. Sakha 104) cultivated on a clay soil at Bahtim Agric. Res. Station during the summer season 2009. The applied $\mathrm{N}$-mineral rates were $0,30,45,75 \mathrm{~kg} \mathrm{~N} / \mathrm{fed}$ in two forms,. i.e., urea (fast $\mathrm{N}$ release) and urea-formaldehyde (slow $\mathrm{N}$-release). The blue green algae (BGA) were applied at the rate of $500 \mathrm{~g} / \mathrm{fed}$, and farmyard (FYM) was added at the rate of 5 ton/fed. The previous materials were applied individually or in combination and then compared to the recommended $\mathrm{N}$-dose, i.e., $90 \mathrm{~kg}$ $\mathrm{N} /$ fed from two $\mathrm{N}$-mineral sources of urea and urea-formaldehyde. The main characteristics of the experimental soil and used farmyard manure were analyzed according to the methods described by Black et al., (1965) and Jackson (1973), and the data are presented in Table 1.

Table 1: The main characteristics of the experimental soil and used farmyard manure.

\begin{tabular}{|c|c|c|c|c|c|}
\hline \multicolumn{4}{|c|}{ Experimental soil } & \multicolumn{2}{|c|}{ Farmyard manure } \\
\hline Character & Value & \multirow{2}{*}{\multicolumn{2}{|c|}{$\begin{array}{l}\text { Chemical analysis } 0 \\
\text { paste: }\end{array}$}} & Character & value \\
\hline \multicolumn{2}{|l|}{ Particle size distribution \%: } & & & i) Weight of $1 \mathrm{~m}^{3}(\mathrm{~kg})$ & 832 \\
\hline Sand & 34.94 & $\mathrm{ECe}\left(\mathrm{dS} \mathrm{m}^{-1}\right)$ & 1.30 & Moisture content \% & 14.95 \\
\hline Silt & 21.81 & Soluble ctions & $\left(m\right.$ molc $\left.L^{-1}\right):$ & $\mathrm{pH}(1: 10$ sus & 7.20 \\
\hline Clay & 43.25 & $\mathrm{Ca}^{++}$ & 4.20 & Organic matter \% & 39.60 \\
\hline Texture grade & Clay & $\mathrm{Mg}^{++}$ & 3.10 & Organic carbon \% & 23.02 \\
\hline Soil pH (1:2.5 suspension) & 7.95 & $\mathrm{Na}^{+}$ & 5.70 & $\mathrm{C} / \mathrm{N}$ ratio & 17.18 \\
\hline Organic matter \% & 1.76 & $\mathrm{~K}^{+}$ & 0.20 & 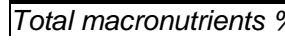 & \\
\hline CEC (Meq $/ 100 \mathrm{~g})$ & 39.60 & Soluble anions & $s\left(m\right.$ molc $\left.L^{-1}\right):$ & $\mathrm{N}$ & 1.34 \\
\hline Available macronutrients ( & $\left.g \mathrm{~kg}^{\top}\right):$ & $\mathrm{CO}_{3}^{--}$ & 0.00 & $P$ & 0.52 \\
\hline $\mathrm{N}$ & 47.00 & $\mathrm{HCO}_{3}{ }^{-}$ & 3.90 & $\mathrm{~K}$ & 1.68 \\
\hline$P$ & 6.20 & $\mathrm{Cl}^{-}$ & 5.00 & & \\
\hline K & 450.00 & $\mathrm{SO}_{4}^{--}$ & 4.30 & & \\
\hline
\end{tabular}

The current experiment was designed as a complete randomized block, with three replicates and an area of $3.5 \times 3 \mathrm{~m}$ for each plot. The recommended doses of phosphorus and potassium were applied rate of 15 $\mathrm{kg} \mathrm{P}_{2} \mathrm{O}_{5}$ /fed and $24 \mathrm{~kg} \mathrm{~K} \mathrm{~K}_{2} \mathrm{O} / \mathrm{fed}$ in the forms of triple superphosphate $(37 \%$ $\left.\mathrm{P}_{2} \mathrm{O}_{5}\right)$ and potassium sulfate $\left(48 \% \mathrm{~K}_{2} \mathrm{O}\right)$, respectively, which were added on the dry soil before planting. While, nitrogen was applied in four equal splits and added from the day of transplanting at an interval of 15 days. However, farmyard manure was thoroughly mixed with soil during its preparing for planting. Three seedlings of thirty days age/hill at spacing $20 \times 20 \mathrm{~cm}$ were transplanted in the permanent filed of the different treated plots. The other usual agricultural practices of growing rice plants were conducted as recommended by Ministry of Agriculture, exception of the factors under study. 
At harvest, plant height $(\mathrm{cm})$ from soil surface to the top panicle of stems was estimated in sample of ten plants, total number of tillers were determined per $\mathrm{m}^{2}$ and 1000 grain weight to the nearest gram was estimated by taking a random sample of thousand grain rough rice. The central area of each plot were harvested, dried and threshed to estimate the grain and straw yields. Total $\mathrm{N}$ in plant parts (straw and grains) were estimated by using the standard method given by Jackson (1973). Biological yield (straw + grain yield/fed) was also estimated. The different criteria were calculated by using following equations:

Harvest index $=$ Grain yield $(\mathrm{kg} / \mathrm{fed})$ Biological yield $(\mathrm{kg} / \mathrm{fed})$

Productivity factor $(\mathbf{k g}$ grain $/ \mathbf{k g ~ N})=\frac{\text { Grain yield }}{\text { Amount of } N \text { applied }}$

Apparent $\mathbf{N}$ recovery $\%=$ Total $\mathrm{N}$-uptake $(\mathrm{kg} / \mathrm{fed})-\mathrm{N}$-uptake from control $(\mathrm{kg} / \mathrm{fed})$ Amount of applied $(\mathrm{kg} / \mathrm{fed})$

(Fageria, et al., 1996).

Moreover, soil samples were taken from each treatment after harvesting, air dried, crushed and passed through a 2-mm sieve for estimating organic carbon according to Nelson and Sommers (1982). Soil pH was measured according to Thomas (1996), whereas electrical conductivity (EC) was measured according to Rhoades (1996). Total nitrogen was determined according to Bremner (1996), while available nitrogen was determined according to Mulvaney (1996). Size distribution of water stable aggregates was determined by using wet-sieving method as described by Yoder (1936). The aggregate size determined as [4 mm (S1), $2 \mathrm{~mm}$ (S2),1 $\mathrm{mm}$ (S3), $0.5 \mathrm{~mm}$ (S4), $0.25 \mathrm{~mm}$ (S5), 0.125 (S6)].

All data were subjected to statistical analysis of variance and treatment means were compared according to the Least Significant Differences (L. S. D.) test method as described by Snedecor and Cochran (1980).

\section{RESULTS AND DISCUSSION}

\section{Rice growth parameter, yield and harvest index}

Some parameters of rice plants, i.e., plant height, number of tillers $/ \mathrm{m}^{2}$ and 1000 grain weight, are presented in Table 2. The applied different $\mathrm{N}$ mineral sources combined with either blue green algae (BGA) or farmyard manure (FYM) were positive and significantly affect.

As for $\mathrm{N}$-mineral, the effective role of urea-formaldehyde as a solely treatment at the recommended dose $(90 \mathrm{~kg} \mathrm{~N} / \mathrm{fed})$ resulted in pronounced increments for the studied plant growth parameters, with a superiority for urea-formaldehyde as compared to the same applied dose of urea. This was true, since urea-formaldehyde is characterized by $\mathrm{N}$-slow release during the growth stages of rice crop. Concerning the effect of different $\mathrm{N}$-mineral sources at the applied different rates combined with BGA or FYM, the obtained data revealed that the greatest values of plant growth parameters under study, i.e., plant height, number of tillers $/ \mathrm{m}^{2}$ and 1000 grain weight were achieved at the combined treatment of urea-formaldehyde at the rate of 
$75 \mathrm{~kg} \mathrm{~N} / \mathrm{fed}+\mathrm{BGA}$ or FYM). This is mainly due to the partial substitution $\mathrm{N}$ mineral (about $25 \%$ ) by a natural $\mathrm{N}$-source derived from either bio (BGA) or organic (FYM) manures for sustaining rice $\mathrm{N}$-requirements. Such condition represents plays a dual benefit, i.e., reducing the cost of used mineral fertilizers and alleviating the hazardous effects of the nitrogenous fertilizers on environment. Moreover, application of such bio-organic manures is not only considered an important storehouse for essential macro and micronutrients of plants but also plays a vital important role for improving soil physical, chemical and biological characteristics. The favorable role of either bio (BGA) or organic (FYM) was more attributed to slow gradually $\mathrm{N}$-release that extends over the growth stages of rice plants, however, released-N plays an effective role in stimulating the build up of amino acids and growth hormones which affected positively on cell division and enlargement. Meanwhile, the applied $\mathrm{N}$-mineral such as urea is considered as soluble $\mathrm{N}$ fertilizer, and then a pronounced amount of soluble $\mathrm{N}$ could be loses under the flooded irrigation system. This means that bio-organic manures appeared to benefit plants more than soluble $\mathrm{N}$-mineral fertilizers where such manures provide growth factors in addition to nutrients. These results are in harmony with those reported by Mady (2004) found that all growth characters significantly increased due to algalization as compared to the non-algalized plots. Also, Amal et al., (2007) who showed that slow release nitrogen fertilizers gave the highest increment in plant height, number of leaves/plant and leaf area index of sorghum plants.

Table 2: Plant height, number of tiller $/ \mathrm{m}^{2}$ and 1000 grain weight as influenced by the applied different treatments.

\begin{tabular}{|c|c|c|c|c|}
\hline Treatment & $\begin{array}{c}\text { N-rate } \\
\text { (kg/fed) }\end{array}$ & $\begin{array}{l}\text { Plant height } \\
\text { (cm) }\end{array}$ & $\begin{array}{c}\text { Number of } \\
\text { tillers/m2 }\end{array}$ & $\begin{array}{l}1000 \text { grain } \\
\text { weight }(\mathrm{g})\end{array}$ \\
\hline Control & 0 & 16.30 & 211.0 & 18.62 \\
\hline Urea & 90 & 21.00 & 402.9 & 22.09 \\
\hline \multirow{3}{*}{ Urea + BGA } & 30 & 18.20 & 289.0 & 19,00 \\
\hline & 45 & 21.57 & 345.2 & 21.43 \\
\hline & 75 & 23.80 & 434.0 & 23.65 \\
\hline \multicolumn{2}{|l|}{ Mean } & 21.19 & 356.1 & 21.36 \\
\hline Urea- formaldehyde & 90 & 22.69 & 488.0 & 24.55 \\
\hline \multirow{3}{*}{ Urea- form. + BGA } & 30 & 21.30 & 319.0 & 20.00 \\
\hline & 45 & 22,00 & 412.0 & 22.32 \\
\hline & 75 & 25.00 & 490.0 & 25.04 \\
\hline \multicolumn{2}{|l|}{ Mean } & 22.96 & 451.0 & 22.45 \\
\hline \multirow{3}{*}{ Urea + FYM } & 30 & 16.36 & 280.0 & 18.45 \\
\hline & 45 & 20.21 & 339.0 & 19.75 \\
\hline & 75 & 21.70 & 421.0 & 21.98 \\
\hline \multicolumn{2}{|l|}{ Mean } & 19.42 & 346.7 & 20.06 \\
\hline \multirow{3}{*}{ Urea- form. + FYM } & 30 & 18.56 & 315.0 & 19.31 \\
\hline & 45 & 22.89 & 397.0 & 21.99 \\
\hline & 75 & 23.80 & 409.0 & 24.76 \\
\hline \multicolumn{2}{|l|}{ Mean } & 21.75 & 373.7 & 22.02 \\
\hline \multicolumn{2}{|c|}{ L.S.D. at .05 } & 0.83 & 5.08 & 5.1 \\
\hline
\end{tabular}


Data in Table 3 showed the pronounced increases of rice straw and grain yields as well as biological yield and harvest index due to the applied different $\mathrm{N}$-sources and rates individually combined with BGA and FYM as compared to the control treatment. The data showed that the application of the recommended dose of urea-formaldehyde was more effective for achieved pronounced increases in the values of straw, grain and biological yields as well as harvest index as compared to the recommended dose of urea. This result may be due to that urea-formaldehyde characterized by $\mathrm{N}$ slow release, which gave a chance for more nitrogen uptake by rice roots through growth stages as well as reduced nitrogen loss from soil by leaching under flooding irrigation system. This finding is confirmed by the result obtained by Zhang et al., (1998) who found that slow release nitrogen fertilizer increased rice yield by $27.5-50.4 \%$ as compared with common urea. Also, Prasad and Datta (1979) found that slow release nitrogen sulfur coated urea increased rice yield as compared with conventional split application urea. Meanwhile, the treatment of urea-formaldehyde at rate of $75 \mathrm{~kg} \mathrm{~N} / \mathrm{fed}+$ BGA or FYM gave the greatest values of straw, grain and biological yields as compared to the different applied ones. These results are in harmony with those reported by Parmer and Sharma (2002) who claimed increased yields of rice crop with the use of different organic materials alone or in combination with mineral fertilizer. Also, Satyanarayana et al., (2002) and Prabu et al., (2003) found that significant response in crop yield and its attributes when mineral fertilizer application combined with FYM and bio-manures. Moreover, Sharief et al., (2006) found that maximum values of straw, grain and biological yields were produced by increasing nitrogen fertilizer up to $60 \mathrm{~kg}$ $\mathrm{N} / \mathrm{fed}$ combined with blue green algae as a bio-fertilizer

Table 3: Straw, grain, biological yields and harvest index as influenced by the applied different treatments.

\begin{tabular}{|c|c|c|c|c|c|}
\hline Treatments & $\begin{array}{l}\text { N-rate } \\
\text { (kg/fed) }\end{array}$ & $\begin{array}{c}\text { Straw yield } \\
(\mathrm{kg} / \mathrm{fed})\end{array}$ & $\begin{array}{c}\text { Grain yield } \\
\text { (kg/fed) }\end{array}$ & $\begin{array}{c}\text { Biological } \\
\text { yield }\end{array}$ & $\begin{array}{c}\text { Harvest } \\
\text { index }\end{array}$ \\
\hline Control & 0 & 1530 & 1014 & 2544 & 39.89 \\
\hline Urea & 90 & 4113 & 3120 & 7233 & 43.13 \\
\hline \multirow{3}{*}{ Urea + BGA } & 30 & 2349 & 1972 & 4321 & 45.64 \\
\hline & 45 & 3534 & 2512 & 6046 & 41.55 \\
\hline & 75 & 4242 & 3833 & 8074 & 47.47 \\
\hline \multicolumn{2}{|l|}{ Mean } & 3374.2 & 3375 & 2772 & 44.88 \\
\hline Urea- formaldehyde & 90 & 4608 & 3536 & 8144 & 43.42 \\
\hline \multirow{3}{*}{ Urea- form. + BGA } & 30 & 2409 & 2650 & 5059 & 52.38 \\
\hline & 45 & 3960 & 2931 & 6891 & 42.53 \\
\hline & 75 & 4852 & 4039 & 8891 & 45.43 \\
\hline \multicolumn{2}{|l|}{ Mean } & 3740.4 & 3740 & 3206 & 46.78 \\
\hline \multirow{3}{*}{ Urea + FYM } & 30 & 2110 & 1296 & 3406 & 38.05 \\
\hline & 45 & 3185 & 2374 & 5559 & 42.71 \\
\hline & 75 & 3837 & 3240 & 7077 & 45.78 \\
\hline \multicolumn{2}{|l|}{ Mean } & 3043.9 & 3044 & 2303 & 42.18 \\
\hline \multirow{3}{*}{ Urea- form. + FYM } & 30 & 2683 & 2485 & 5168 & 48.08 \\
\hline & 45 & 3374 & 2733 & 6107 & 44.76 \\
\hline & 75 & 4504 & 3584 & 8088 & 44.31 \\
\hline \multicolumn{2}{|l|}{ Mean } & 3520.3 & 3520 & 2934 & 45.71 \\
\hline \multicolumn{2}{|c|}{ L.S.D. at .05 } & 11.31 & 11.00 & 19.00 & 8.19 \\
\hline
\end{tabular}


Concerning the harvest index of rice crop, data presented in Table 3 clearly indicated that its value was affected significantly by applied different nitrogen sources and rates as solely or combined treatments with BGA or FYM. Among the applied treatments, the greatest harvest index values were recorded at the combined treatments of urea- formaldehyde + BGA.

\section{Nitrogen uptake by rice straw and grain}

Data of nitrogen uptake by rice straw and grain as well as total nitrogen uptake $\mathrm{kg} / \mathrm{fed}$ as influenced by different nitrogen sources and rates, as solely treatments or combined with BGA or FYM are presented in Table 4.

Table 4: $\mathrm{N}$-uptake (kg/fed) by straw, grain and biological yield as influenced by the applied different treatments.

\begin{tabular}{|c|c|c|c|c|}
\hline Treatments & $\begin{array}{c}\text { N-rate } \\
\text { (kg/fed) }\end{array}$ & $\begin{array}{c}\text { N-uptake by } \\
\text { straw }\end{array}$ & \begin{tabular}{|c|} 
N-uptake by \\
grain
\end{tabular} & $\begin{array}{c}\mathrm{N} \text {-uptake by } \\
\text { biological yield }\end{array}$ \\
\hline Control & 0 & 5.36 & 15.27 & 20.63 \\
\hline Urea & 90 & 15.51 & 40.68 & 56.19 \\
\hline \multirow{3}{*}{ Urea + BGA } & 30 & 8.46 & 21.69 & 30.15 \\
\hline & 45 & 14.49 & 32.66 & 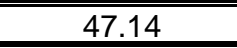 \\
\hline & 75 & 17.94 & 42.96 & 60.90 \\
\hline \multicolumn{2}{|l|}{ Mean } & 14.29 & 36.77 & 51.06 \\
\hline Urea- formaldehyde & 90 & 23.50 & 53.04 & 76.54 \\
\hline \multirow{3}{*}{ Urea- form. + BGA } & 30 & 11.08 & 28.42 & 39.50 \\
\hline & 45 & 19.01 & 40.72 & 59.73 \\
\hline & 75 & 24.74 & 57.85 & 82.60 \\
\hline \multicolumn{2}{|l|}{ Mean } & 18.28 & 50.67 & 68.94 \\
\hline \multirow{3}{*}{ Urea + FYM } & 30 & 7.99 & 16.09 & 24.08 \\
\hline & 45 & 13.76 & 27.00 & 40.76 \\
\hline & 75 & 16.98 & 40.90 & 57.88 \\
\hline \multicolumn{2}{|l|}{ Mean } & 12.91 & 29.00 & 41.91 \\
\hline \multirow{3}{*}{ Urea- form. + FYM } & 30 & 9.34 & 31.00 & 40.34 \\
\hline & 45 & 15.74 & 36.51 & 52.25 \\
\hline & 75 & 19.36 & 45.93 & 65.29 \\
\hline \multicolumn{2}{|l|}{ Mean } & 14.81 & 39.15 & 53.96 \\
\hline \multicolumn{2}{|l|}{ L.S.D. at .05 } & 0.07 & 4.19 & 7.29 \\
\hline
\end{tabular}

Data revealed that application of different nitrogen treatments were significant affect $\mathrm{N}$ uptake by rice plants as compared to the control treatment. The maximum total nitrogen uptake $(82.60 \mathrm{~kg} / \mathrm{fed})$ was achieved at the combined treatment of urea-formaldehyde at rate of $75 \mathrm{~kg} \mathrm{~N} / \mathrm{fed}+\mathrm{BGA}$. On the other hand, the effective role of either BGA or FYM combined with highest rate of nitrogen $(75 \mathrm{~kg} \mathrm{~N} / \mathrm{fed})$ was almost superior of total $\mathrm{N}$-uptake than the recommended dose of nitrogen fertilizer. These results may be attributed to when oxygen evolved in water by photosynthetic activity of the algae provide an aerobic condition for the growth of the root system of rice plants, and consequently produces more numerous root hairs proportionally increased their absorptive surface that improved nutrients uptake. These findings are confirmed by Shah and Ishaq (2006) who reported that combination of organic and inorganic $\mathrm{N}$ resulted in greater $\mathrm{N}$-uptake from than those obtained when each was applied singly. In addition, Asghar et al., 


\section{Azza R. Ahmed et al.}

(2006) showed that enriched compost with $50 \%$ recommended nitrogen fertilizer gave almost same results as the $100 \%$ fertilizer alone, thus saving half of the $\mathrm{N}$-mineral fertilizer.

\section{Nitrogen use efficiency}

Nitrogen use efficiency in terms of productivity factor and apparent $\mathrm{N}$ recovery clearly showed that application of different nitrogen sources at recommended dose or combined with either BGA or FYM caused a higher value of nitrogen use efficiency, especially when urea-formaldehyde combined with BGA was applied (Fig. 1 a \& b).

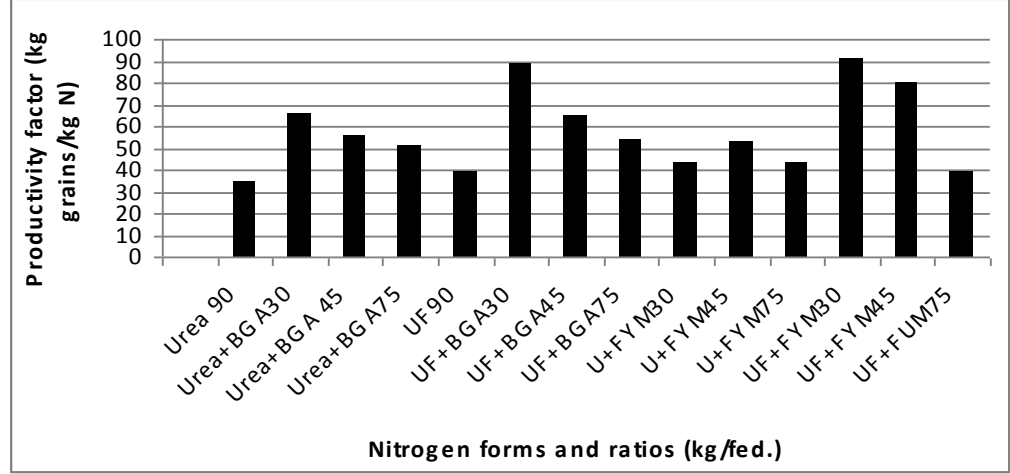

\section{Fig.(1-a) Effect of different treatments on productivity factor}

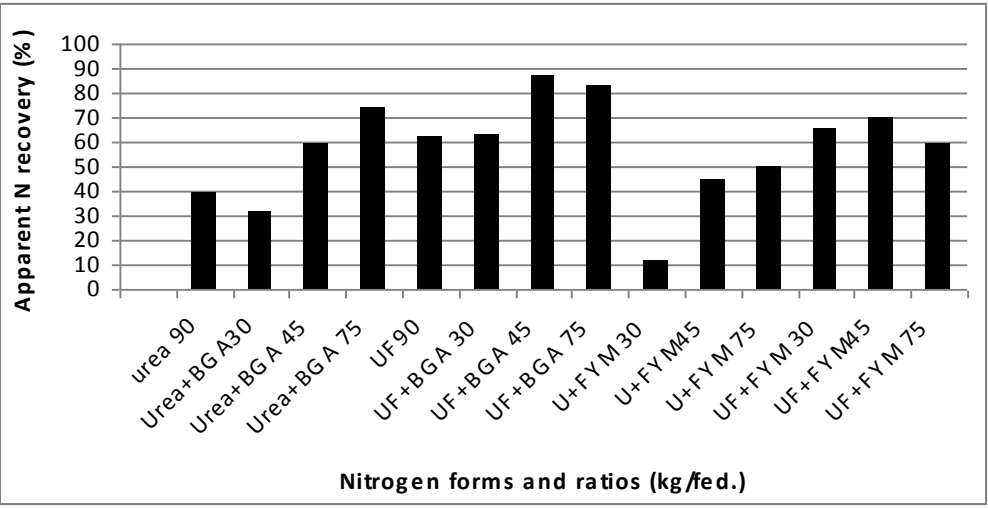

Fig.(1-b) Effect of different treatments on N-recovery

Productivity factor or apparent $\mathrm{N}$-recovery were relatively higher at the treatment of recommended dose of urea-formaldehyde as compared to urea. Concerning the interaction between different nitrogen sources and rates combined with either BGA or FYM, the data indicated that the greatest values of productivity factor $(91.11 \mathrm{~kg}$ grain per $\mathrm{kg} \mathrm{N}$ ) and apparent $\mathrm{N}$-recovery $\mathrm{N}$ $(86.88 \%)$ were detected at the treatments of urea-formaldehyde at rate of 30 $\mathrm{kg} \mathrm{N} / \mathrm{fed}+\mathrm{FYM}$, and urea-formaldehyde at rate of $45 \mathrm{~kg} \mathrm{~N} / \mathrm{fed}+\mathrm{BGA}$, respectively.

The higher nitrogen use efficiency was occurred due to the applied different nitrogen sources combined with BGA or FYM, might be due to lower 
$\mathrm{N}$-loss synchronization of $\mathrm{N}$ supply with crop needs. Also, apparently nitrogen fixation of blue green algae enhancement effect on the productivity of rice plants grown on the field. These results were in conformity with the findings reported by Manjappa et al., (1994) who reported that blended inorganic fertilizers increased use efficiency of nutrients. In addition Abdullah (2004) reported that blue green algae (BGA) is supplying $N$ to rice field is well recommended.

\section{Some soil properties as affected by the applied treatments}

Data in Table 5 represent the effect of applied different nitrogen sources and rates as solely or combined with BGA or FYM on some soil properties, i.e., organic matter content, $\mathrm{pH}, \mathrm{EC}$, total and available nitrogen. The detected changes in some soil properties showed that the greatest mean value of soil organic matter content $2.55 \%$ was obtained at the combined treatment of urea-formaldehyde + FYM as compared to the lowest value of $1.79 \%$ at the control treatment. A combination of FYM or BGA with chemical fertilizer proved further helpful in increasing the organic matter level of the soil, besides a higher return of organic residues of rice roots due to stubble from higher yielding crops. In addition, organic matter content in the remaining fertilizers treatments was at par with that in the control treatment (Smiciklas et al., 2002 and Sarwar et al., 2003).

Table 5: Some soil characteristics as influenced by the applied different treatments.

\begin{tabular}{|c|c|c|c|c|c|c|}
\hline Treatment & $\begin{array}{c}\text { N-rate } \\
\text { (kg/fed) }\end{array}$ & $\begin{array}{c}\mathrm{ECe} \\
\left(\mathrm{dS} \mathrm{m}^{-1}\right)\end{array}$ & $\begin{array}{l}\text { Soil } \\
\text { pH }\end{array}$ & $\begin{array}{l}\text { Organic } \\
\text { matter } \%\end{array}$ & $\begin{array}{c}\text { Total } \\
\mathrm{N} \% \\
\end{array}$ & $\begin{array}{c}\text { Available N } \\
\left(\mathrm{mg} \mathrm{kg}^{-1}\right)\end{array}$ \\
\hline Control & 0 & 1.17 & 8.00 & 1.79 & 0.067 & 48 \\
\hline Urea & 90 & 0.75 & 7.97 & 1.83 & 0.085 & 50 \\
\hline \multirow{3}{*}{ Urea + BGA } & 30 & 0.65 & 7.69 & 1.92 & 0.094 & 52 \\
\hline & 45 & 0.58 & 7.82 & 1.94 & 0.097 & 55 \\
\hline & 75 & 0.47 & 7.75 & 2.03 & 0.100 & 57 \\
\hline \multicolumn{2}{|l|}{ Mean } & 0.59 & 7.75 & 1.96 & 0.097 & 55 \\
\hline Urea- formaldehyde & 90 & 0.51 & 7.60 & 1.85 & 0.089 & 54 \\
\hline \multirow{3}{*}{ Urea- form. + BGA } & 30 & 0.47 & 7.77 & 2.10 & 0.096 & 55 \\
\hline & 45 & 0.48 & 7.52 & 2.15 & 0.099 & 58 \\
\hline & 75 & 0.44 & 7.51 & 2.21 & 0.104 & 62 \\
\hline \multicolumn{2}{|l|}{ Mean } & 0.47 & 7.60 & 2.15 & 0.100 & 58 \\
\hline \multirow{3}{*}{ Urea + FYM } & 30 & 0.80 & 7.37 & 2.42 & 0.115 & 67 \\
\hline & 45 & 0.82 & 7.43 & 2.50 & 0.126 & 70 \\
\hline & 75 & 0.81 & 7.21 & 2.55 & 0.132 & 74 \\
\hline \multicolumn{2}{|l|}{ Mean } & 0.81 & 7.34 & 2.49 & 0.124 & 70 \\
\hline \multirow{3}{*}{ Urea- form. + FYM } & 30 & 0.70 & 7.62 & 2.47 & 0.121 & 69 \\
\hline & 45 & 0.78 & 7.47 & 2.58 & 0.134 & 72 \\
\hline & 75 & 0.79 & 7.44 & 2.60 & 0.157 & 75 \\
\hline \multicolumn{2}{|l|}{ Mean } & 0.76 & 7.51 & 2.55 & 0.137 & 72 \\
\hline \multicolumn{2}{|c|}{ L.S.D. at .05 } & 0.05 & 0.08 & 0.36 & N.S & 5.8 \\
\hline
\end{tabular}

Regarding soil $\mathrm{pH}$, the data indicated that application of all treatments recorded slightly decreases in the $\mathrm{pH}$ values of the soil. The decreases in soil $\mathrm{pH}$ ranged between 0.03 and 0.48 units by applying urea and ureaformaldehyde at the recommended dose, respectively. When using urea or urea-formaldehyde combined with BGA or FYM, soil pH tended to decrease 
by $0.18,0.48,0.57$ and 0.53 units for the treatments of urea + BGA, ureaformaldehyde + BGA, urea + FYM and urea-formaldehyde + FYM as compared to the control, respectively. The reduction in the values of soil $\mathrm{pH}$ might be attributed to the production of $\mathrm{CO}_{2}$ and organic acids due to incorporation of organics. Arafat (1994) observed that application of ureaformaldehyde as organic manures to the soil had a slight effect on soil $\mathrm{pH}$. The effect on $\mathrm{pH}$ may be explained by the production of the organic acids and hydrogen ion $\left(\mathrm{H}^{+}\right)$. The decomposition process accelerates the release of $\mathrm{CO}_{2}$ organic acids, which would reduce soil $\mathrm{pH}$. These findings are in agreement with the results obtained by Sarwar et al., (2008) who found that application of compost alone and in combination with chemical fertilizer reduced the soil $\mathrm{pH}$ significantly as compared to control.

The ECe values of the treated soil showed significant decreases due to the applied different treatments as compared to the initial soil (Tables 1 and 5). Application of urea or urea-formaldehyde individually at the recommend dose reduced the ECe by about 36 and $56 \%$ as compared to the control, respectively. The application of urea and urea-formaldehyde combined with $B G A$ resulted in reduced ECe by about 50 and $59 \%$, respectively. The corresponding reductions in case of combined treatment with FYM were about 30 and $33 \%$, respectively. These findings are confirmed by those reported by Beheiry (2003) who showed that application of any of the organic manure such as FYM applied as either individually or in combination, decreased soil salinity.

Data in Table 5 also indicated that total nitrogen content in soil tended to increase in the treatment receiving urea-formaldehyde combined with FYM or BGA. Such observation was emphasized by Gurung and Prasad (2005) who found that blue green algae increase the $\mathrm{N}$ content in the soil. Whereas the greatest value of total $\mathrm{N}$ content was obtained due to the applied treatment of $75 \mathrm{~kg} \mathrm{~N} / \mathrm{fed}$ as urea-formaldehyde combined with FYM. These results can be attributed to slow release of nitrogen from both FYM as an organic manure and also urea-formaldehyde as $\mathrm{N}$-mineral fertilizer.

Available nitrogen, (Table 5) revealed that all applied treatments could be result in higher available $\mathrm{N}$ contents in the treated soil as compared with the control treatment. The greatest values of $\mathrm{N}$-available were obtained due to application of urea- formaldehyde as $\mathrm{N}$-mineral source combined with FYM. Whereas, nitrogen availability in soil maintained at a higher level by urea-formaldehyde as slow release nitrogen fertilizer as compared with urea as well as coupled with reduced losses due to $\mathrm{NH}_{3}$ volatilization and leaching. Such finding is emphasized by Gupta et al., (2000) who reported that, combined application of urea and farmyard manure significantly enhanced available $\mathrm{N}$ status over similar $\mathrm{N}$ addition through urea alone.

\section{Aggregate size distribution}

Aggregate size distribution was demonstrated in Fig. 2, and showed that the aggregate sizes of 4.0 (S1), 2.0 (S2), 1.0 (S3) and 0.5 (S4) mm diameter tended to increase, especially in the plots receiving different nitrogen rates combined with BGA or FYM. In addition, a pronounced positive effect was observed with the applied as solely or combined treatments as compared to the urea form. Also, the treatments of urea or urea- 
formaldehyde combined with FYM exhibited significantly higher amounts of the above-mentioned proportion of aggregate size distribution as compared to the plot received both urea forms + BGA. Contrary, the proportion of aggregate sizes 0.25 (S5) and $0.125 \mathrm{~mm}$ (S6) diameter were represented a higher percentages in the control treatment.

Increasing the percentage of macro-aggregate and reducing the percentage of micro-aggregate with either BGA or FYM, may be due to that, these materials play a positive role as a cementing agent through the released active organic acids and polysaccharides during the decomposition of organic residues by microbial activity. Besides, these compounds, particularly polysaccharides, are made of fibers that can also entangle clay particles and form clusters of clay domains. These clusters or microaggregates, in turn, grow and take the shape of macro-aggregates and subsequently of larger soil aggregates. These results are in harmony with those reported by Ranjan et al., (2006). Such favorable effects of bio-organic manure on improving soil aggregation status as well as modifying soil structure, and in turn ameliorating soil aeration and soil moisture regime. Therefore, the application of these bio-organic manures represents a useful case for the soils, which positively reflected on the grown plants (Rogers and Burns, 1994 and Hegde et al., 1999).

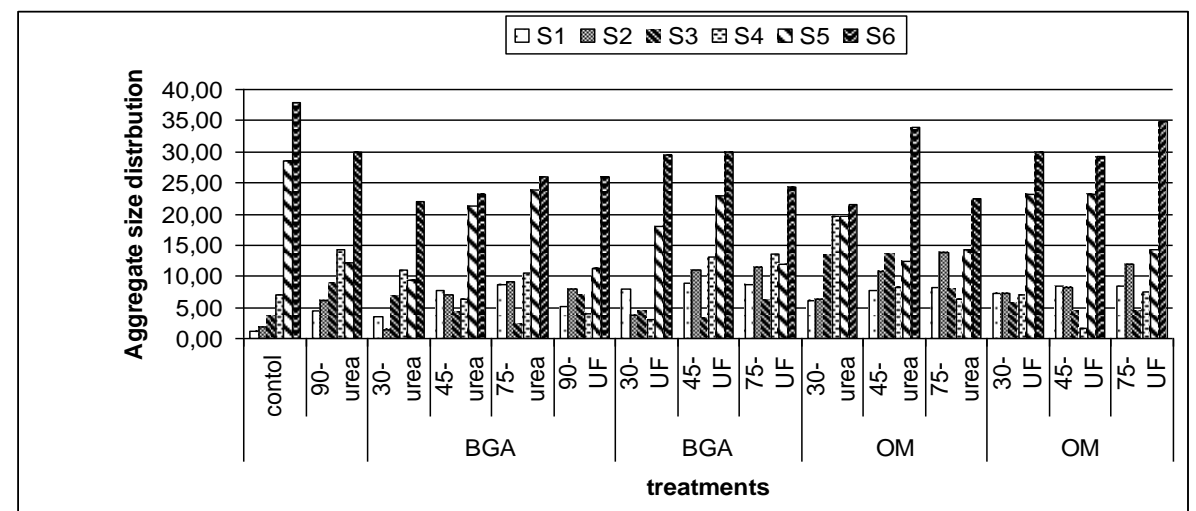

Fig. (2): Effect of different treatments on aggregate size distribution.

\section{Conclusion}

From the results of this study, it could be concluded that application of both BGA and FYM are more important in rice fields, however, they contribute significantly towards maintaining and improving not only the productivity of rice but also improving the chemical, physical and biological properties of soil besides increasing the nitrogen use efficiency. So, the application of the natural bio and organic manures, i.e., blue green algae or local organic farmyard manure are considered the best option not only for maximizing rice grain yield, its quality and reducing the harmful effects of using nitrogenous chemical fertilizers, but also for sustaining soil fertility status. Moreover, the application of bio-organic manures leads to rationalize use of $\mathrm{N}$-mineral fertilizer for the growing crop, which is surplus point for 
sustainable agriculture system, as well as represents a solving for the problems of chemical residues in the export market commodities.

\section{REFERENCES}

Abdullah, M.A. (2004). Sexton and Nitrogen Effects on Yield and N, P Uptake of rice (Oryza sativa L. Cv. Hassawi). Scientific Journal of King Faisal University. Basic and Applied Sciences. 5 (1): 93-101.

Allen, S.E. (1984). Slow-release nitrogen fertilizers. In; Nitrogen in crop production. Eds. R.D. Hauck et al. P195-206. ASA,CSSA, SSSA Madison Wisconsin USA.

Amal, G.A.; M.Z. Nabila and M.S. Hassanein (2007). Response of grain sorghum to different nitrogen sources. Research Journal of Agriculture and Biological Sciences, 3(6): 1002-1008.,

Arafat, S.M. (1994). Evaluation of sugar cane filter mud on improving soil characteristics and water melon yield. Egypt. J. Appl. Sci., 9. (9): 287295

Asghar, H.N.; M. Ishaq; Z.A. Zahir; M. Khalid and M. Arshad (2006). Response of radish to integrated use of nitrogen fertilizer and recycled organic waste. Pak. J. Bot., 38(3): 691-700 (c.f. Egyptian J. Desert Res., 53:101-118).

Begum, Z.N.T; R. Mandal; F. Akhter and N.C. Das (1990). Residual effect of cyanobacteria on the growth and yields of rice. Pp. 379-381 in 'Perspectives in phycology', Ed. by V.N. Rajarao. Today and Tomorrow's Printers \& Publishers: New Delhi, India.

Beheiry, G.G.S. (2003). Application of farmyard manure by products and their impact on the chemical properties and productivity of calcareous soil, Egyptian J. Desert Res., 53 101-114

Bhuiya, Z.H., A.K.M.N. Islam, M.A. Hashem, Z.N.T. Begum and M.M. Rahman (1984). Effect of cyanobacteria as biofertilizer on rice. Bangladesh Journal of Agriculture, 9: 47-51.

Black, C.A.; D.D. Evans ; L.E. Ensminger ; L.L. White, and F.E. Clark, (1965). Methods of soil Analysis. Amer. Soc. Agron. Inc., Pub., Madison, Wisc., USA.

Brady, N.C. (2005). The nature and properties of soil (13 Ed.). Macmillan Publishing Co. New York.

Bremner, J.M. (1996). Nitrogen-Total. pp. 1085-1122. In: Sparks, D.L. (ed). Methods of soil analysis, Part 3: Chemical methods, SSSA Book series 5, Madison, WI, USA.,\#

Choudhury, A.T.M.A. and Y.M. Khanif (2004). Effects of nitrogen and copper fertilization on rice yield and fertilizer nitrogen efficiency: A $N$ tracer study. Pakistan Journal of Scientific and Industrial Research,47: 50-55.

Choudhury, A.T.M.A. and I.R. Kennedy (2005). Nitrogen fertilizer losses from rice soils and control of environmental pollution problems. Communications in Soil Science and Plant Analysis, 36: 1625-1639.

De Datta, S.K. and R.J. Buresh (1989). Integrated nitrogen management in irrigated rice. Advances in Soil Science, 10: 143-169. 
Fageria, N. K.; V. C. Baligar, and C. A. Jonses (1996). Growth and mineral nutrition of field crops. Printed in the U.S.A. by Marcel Dekker, Inc. chapter 9, pp 324- 325.

Gupta, R.K.; B.R. Arora, K.N. Sharma and S.K. Ahluwalia (2000). Influence of biogas slurry and farmyard manure application on the changes in soil fertility under rice - wheat sequence. Journal of the Indian Society of Soil Science., 48 (3): 500-505.

Gurung, S. and B.N. Prasad (2005). Azolla and cyanobacteria (BGA): potential biofertilizers for rice. Scientific World, 3 (3): 85-89.

Hegde, D.M.; B.S. Dwivedi and S.N.S. Babu (1999). Biofertilizers for cereal production in India- A Review Indian Journal of Agricultural Sciences, 69 (2):73-83.

Hussein, H. F. and S. M. A. Radwan (2001). Effect of biofertilization with different levels of nitrogen and phosphorus on wheat and associated weeds under weed control treatments. Pakistan Journal of Biological Sciences, 4: $435-441$.

Jackson, M.L. (1973). "Soil Chemical Analysis". Prentice Hall of India Pvt., New Delhi.

Kreem, M.K.E. (1993). Effect of different nitrogen rates and comp nitrification inhibitor on growth and yield of rice. J. Agric. Res. Tanta Univ., 19: 525536.

Mady, A.A. (2004). Effect of irrigation intervals and algalization rates on some rice cultivars (Oryza sativa L). J. Agric. Res. Tanta Univ., 30 : 191-209.

Mandal, B.; P.L.G. Velk and L.N. Mandal. (1999). Beneficial effects of bluegreen algae and Azolla, excluding supplying nitrogen, on wetland rice fields: a review. Bio. Fertil. Soils, 24: 329-342.

Manjappa, K.; H.T. Chandranath; A.K. Guggari and B.K. Desai (1994). Ways and means of increasing NUE in rice fields. Agricultural Reviews, Karnal, 15(3/4): 195-204.

Mulvaney, C.M. (1996). Nitrogen-Inorganic forms. pp. 1123-1184. In: Sparks, D.L. (Ed). Methods of soil analysis, Part 3: Chemical methods, SS SA Book Series 5, Madison, WI, USA.

Neelam, K.C. and N. Chopra (2000). Effect of row spacing and nitrogen level on growth, yield and seed quality of rice ( Oryza sativa) under transplanted conditions. Indian J. Agron., 45: 304-308.

Nelson, D.W. and Sommers, L.E., (1982). Total carbon, organic carbon and organic. In Methods of soil analysis, Page, A.L.; Miller, R.H.; Keeney, D.R., (Eds.), American Soc. of Agronomy, Madison, Wisconsin, USA. 539-549.

Parmer, D.K. and V. Sharma. (2002). Studies on long-term application of fertilizers and manure on yield of maize-wheat rotation and soil properties under rainfed conditions in Western-Himalayas. Journal of the Indian Society of Soil Science, 50: 311-312.

Prabu, T.; P.R. Narwadkar; A. K. Sanindranath and M. Rafi (2003). Effect of integrated nutria management on growth and yield of okra (Abelmoschus esculentus L. Moench) cv. Parbha Kranti. Orissa. J. Hort., 31: 17-21. 
Prasad, R. and S.K. De Datta (1979). In Nitrogen and Rice. International Rice Research Institute, Los Banos, 465434.

Ranjan, B.; S. Chandra; R.D. Singh; S. Kundu; A.K. Srivastva and H.S. Gupta (2006). Long-term farmyard manure application effects on properties of a silty clay loam soil under irrigated wheat-soybean rotation. Soil \& Tillage Research, 94: 386-396.

Rhoades, J.D. (1996). Salinity: Electrical conductivity and total dissolve solids. Pp. 417-436. In: Sparks, D.L. (Ed). Methods of Soil Analysis. Part 3 Chemical methods. SSSA. Madison, WI. USA.

Rogers, P.A. and J.K. Ladha (1992). Biological $\mathrm{N}_{2}$ fixation in wetland rice fields: estimation and contribution to nitrogen balance. Dev. Plant Soil Sci. Dordrecht: Kluwer Academic Publishers, 49: 41-55.

Rogers, S.L. and R.G. Burns (1994). Changes in aggregate stability, nutrient status, indigenous microbial populations, and seedling emergence, following inoculation of soil with Nostoc muscorum. Biology and Fertility of Soils, 18 (3):209-215.

Sarwar, G.; N. Hussain; F. Mujeeb; H. Schmeisky and G. Hassan (2003). Biocompost application for the improvement of soil characteristics and dry matter yield of Lolium perenne (Grass). Asian J. Plant Sci., 2(2): 237-241.

Sarwar, G.H.; N. Hussain; S. Muhammad; M. Ibrahim and E. Safdar (2008). Improvement of soil physical and chemical properties with compost application in rice-wheat cropping system. Pak. J. Bot., 40(1): 275-282.

Satyanarayana, V.; P.V. Vera Prasad; V.R.K. Murthy and K.J. Boote (2002). Influence of integrated use of farmyard manure and inorganic fertilizers on yield and yield components of irrigated lowland rice. Journal of Plant Nutrition, 25(10): 2081-2090.

Shah, Z. and M. Ishaq (2006). Effect of integrated use of farm yard manure and urea on yield and nitrogen uptake of wheat. J. of Agric. and Bio. Sci., 1(1): 60-64

Sharief, A.E.; S.E. El-Kalla; A.T. El-Kassaby; M.H. Ghonema and G.M.Q. Abdo (2006). Effect of bio-chemical fertilization and times of nutrient foliar application on growth, yield and yield components of rice. Journal of Agronomy, 5 (2): 212-219.

Shoji, S. and T. Mae (1984). Dynamics of inorganic nutrients and water. In: Cophysiology of Crops, Buneido, Tokyo in Japanese 97-172 pp.

Smiciklas, K.D.; P.M. Walker and T.R. Kelley (2002). Utilization of Compost (Food, Paper, Landscape and Manure) in Row Crop Production. Department of Agriculture and Health Sciences, Illinois State University, USA.

Snedecor, G. W. And W. G. Cochran (1980). One way classification- Analysis of Variance - The random effect model - Two way classification (Eds) Statistical Methods. The lowa State Univ. Press, Ames, lowa, USA : 215-273.

Thomas, G.W. (1996). "Soil pH and soil acidity", pp. 475-490. In: Sparks, D.L. (Ed.). Methods of Soil Analysis, Part 3: Chemical Methods, SSSA Book Series 5, Madison, WI, US. 
Yoder, R. E. (1936). A direct method of aggregate analysis of soils and a study of the physical nature of erosion losses. J. Amer. Soc. Agron. 28:337-351.

Zia, M.S. (1993). Soil Fertility Evaluation and Management for Flooded lowland rice soils of Pakistan. Ph. D. Dissertation, Kyoto University, Japan.

Zhang, C.L.; X.M. Zhu and S.N. Hu (1998). Studies of the effect of slowrelease urea and nitrogen use efficiency. Soils and Fertilizers, Beijing, 6: 11-13.

النترورجينية التسميد الحيوى والعضوي في استتمرارية إمداد محصول الأرز بالإحتياجـات

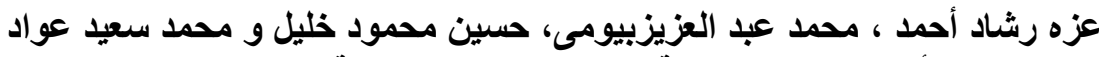

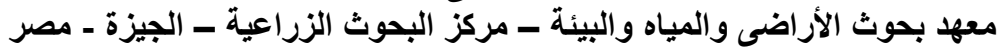

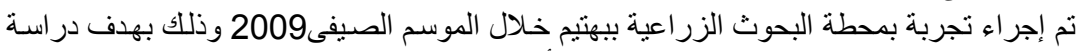

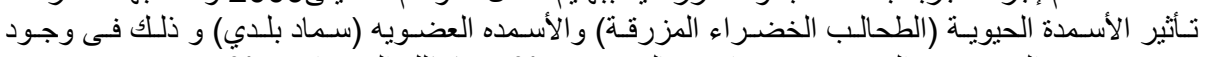

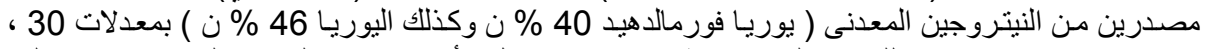

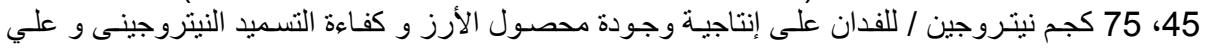
بوض خو اص التربة الطينية. وقد أوضحت النتائج أن: الطينا،

إضافة اليوريا فورمالدهيد مع الطحالب الخضر اء المزرقة أدت إلى الحصول على أعلى قيم لقياس

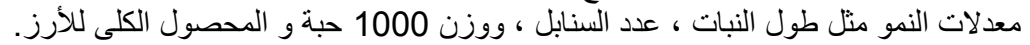

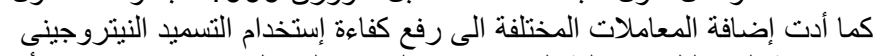

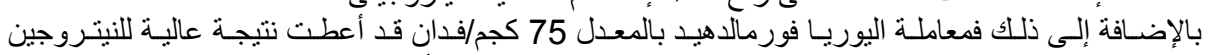

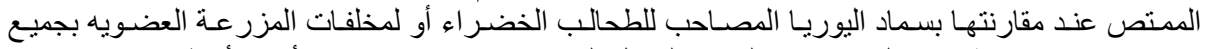

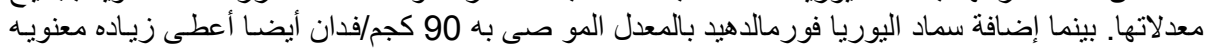

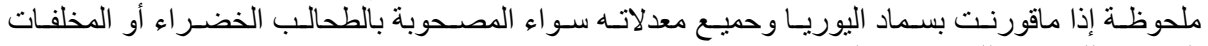

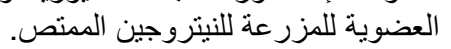

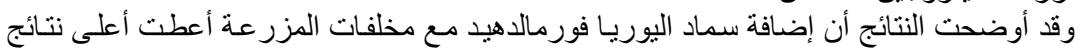

معنوية لمحتوى المادة العضوية ، وكل من نسبة النيتروجين الميسر و نسبة النيتروجين الكلى عند مقارنتها

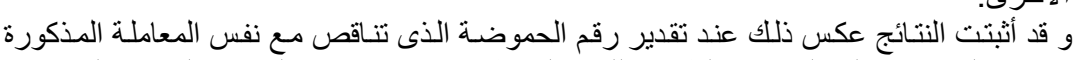

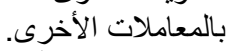

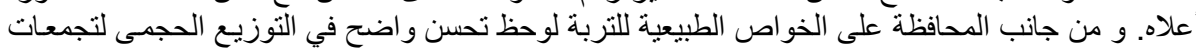

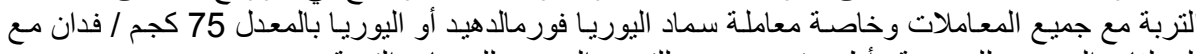

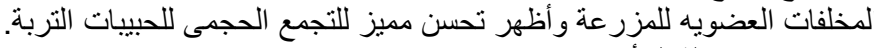

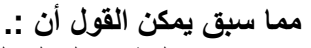

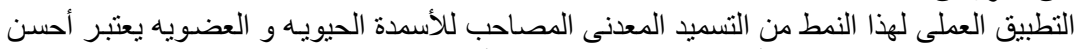

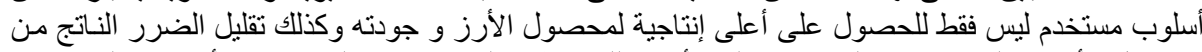

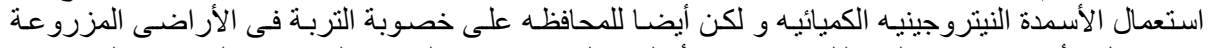

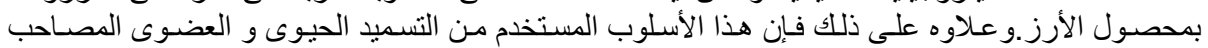

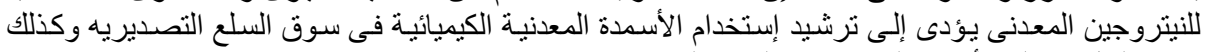
كبداية لحل مشكلة الأسمدة المعدنيه في النظام الزراعى.

كلية الزراعة - جامعة المنصورة

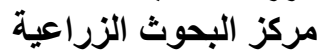

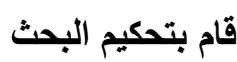

أ. أد / أحمد عبد القادر طه البه

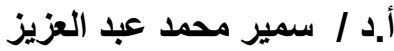

